\title{
PENGGUNAAN INDIRECT EVIDENCE (ALAT BUKTI TIDAK LANGSUNG) DALAM PROSES PEMBUKTIAN DUGAAN PRAKTIK KARTEL DI INDONESIA OLEH KPPU
}

\author{
Ibnu Akhyat \\ (Mahasiswa Magister Ilmu Hukum Universitas Tarumanagara) \\ (E-mail: ibnu.akhyat@gmail.com)
}

Received: 2 Juli 2018; Accepted: 18 Juni 2019; Published: 30 Juni 2019

\begin{abstract}
:
The regulation concerning business competition law in Indonesia is regulated in Law Number 5 Year 1999 concerning Prohibition of Monopolistic Practices and Unfair Business Competition which was enacted on March 5, 1999 and entered into force one year later. With the enactment of Law No. 5 of 1999 every business actor must implement provisions on how to run his business activities in a fair and conducive manner.

In the case of alleged violation of Law Number 5 Year 1999, both Article 5, Article 9, and Article 11, require fulfillment of agreement element to prove that violation of the provisions of those Articles has occurred. However, since the cartel is usually established and done in secret, the proof of the existence of the cartel agreement creates a problem. The Monopoly Practices Law and Unfair Business Competition in Indonesia have not regulated the use of indirect evidence as evidence to prove the occurrence of a cartel. In such case, KPPU is difficult to find any written agreement or other document that explicitly contains agreement on price, marketing area, or production of goods and / or services among business actors.
\end{abstract}

Keywords: Indirect Evidence, Cartels, Business Competition

\section{Pendahuluan}

\section{A. Latar Belakang}

Pengaturan mengenai hukum persaingan usaha di Indonesia diatur dalam Undang-Undang Nomor 5 Tahun 1999 tentang Larangan Praktik Monopoli dan Persaingan Usaha Tidak Sehat yang diundangkan pada tanggal 5 Maret 1999 dan mulai berlaku satu tahun kemudian. Dengan diberlakukannya Undang-Undang
Nomor 5 Tahun 1999 setiap pelaku usaha harus melaksanakan ketentuanketentuan mengenai bagaimana menjalankan kegiatan usahanya secara fair dan kondusif.

Secara umum materi UndangUndang Nomor 5 Tahun 1999 mengandung enam bagian pengaturan yang terdiri dari perjanjian yang dilarang, kegiatan yang dilarang, posisi dominan, Komisi Pengawas 
Persaingan Usaha (KPPU), penegakan

hukum, dan ketentuan lain-lain.

Berdasarkan pengaturan tersebut di atas, salah satu bentuk perjanjian yang dilarang dalam Undang-Undang Nomor 5 Tahun 1999 adalah kartel.

Kartel pada dasarnya adalah perjanjian satu pelaku usaha dengan pelaku usaha pesaingnya untuk menghilangkan persaingan di antara keduanya. Secara klasik kartel dapat dilakukan melalui tiga hal yaitu harga, produksi, dan wilayah pemasaran. ${ }^{1}$ Dalam Undang-Undang Nomor 5 Tahun 1999, larangan mengenai perjanjian penetapan harga diatur dalam Pasal 5, larangan mengenai perjanjian pembagian wilayah diatur dalam Pasal 9, dan larangan mengenai perjanjian pengaturan produksi dan/atau pemasaran diatur dalam Pasal 11. Tujuan utama para pelaku usaha melakukan perjanjian kartel adalah untuk meningkatkan keuntungan di antara anggota kartel dan hal ini akan merugikan konsumen, karena konsumen tidak punya pilihan lain di

1 Farid Nasution dan Retno Wiranti, Kartel dan Problematikanya, (KOMPETISI, Media Berkala Komisi Pengawas Persaingan Usaha, Edisi, 11 tahun 2008), 4.

2 Udin Silalahi, Indirect evidence dalam Hukum Persaingan Usaha (Jurnal Hukum Bisnis 2013), 37 pasar yang bersangkutan terhadap produk tertentu, baik dari aspek harga maupun kualitasnya. ${ }^{2}$

Definisi pasar bersangkutan merupakan tahapan awal dari analisis persaingan usaha yang penerapannya dilakukan secara kasus per kasus. Melalui penetapan pasar bersangkutan dapat diperoleh informasi serta ukuran yang jelas mengenai pasar, pelaku usaha yang terlibat, serta dampak anti persaingan dari setiap dugaan pelanggaran Undang-Undang Nomor 5 Tahun 1999. Pendefinisian pasar bersangkutan merupakan bagian penting dari upaya pembuktian dugaan pelanggaran Undang-Undang Nomor 5 Tahun $1999 .{ }^{3}$

Selain pasar bersangkutan, dalam rangka membuktikan terjadinya pelanggaran terhadap ketentuan dalam Undang-Undang Nomor 5 Tahun 1999, KPPU harus menganalisis dan membuktikan bahwa unsur-unsur dari masing-masing pasal telah terpenuhi. Dalam kasus dugaan pelanggaran Undang-Undang Nomor 5 Tahun

3 Susanti Adi Nugroho, Hukum Persaingan Usaha di Indonesia dalam Teori \& Praktik Serta Penerapan Hukumnya (Jakarta: Kencana Prenadamedia Group, 2012), 123. 
1999, baik Pasal 5, Pasal 9, maupun

Pasal 11, mensyaratkan pemenuhan unsur perjanjian untuk membuktikan bahwa telah terjadi pelanggaran atas ketentuan pasal-pasal tersebut. Namun demikian karena kartel biasanya dibentuk dan dilakukan secara rahasia maka pembuktian keberadaan perjanjian kartel menimbulkan permasalahan ${ }^{4}$. Dalam hal ini KPPU sulit untuk menemukan adanya perjanjian tertulis maupun dokumen lain yang secara eksplisit berisi kesepakatan mengenai harga, wilayah pemasaran, maupun produksi atas barang dan/atau jasa di antara pelaku usaha. Oleh karena itu dalam perkembangannya untuk membuktikan terjadinya kartel dibutuhkan alat bukti yang disebut dengan bukti tidak langsung (indirect evidence).

Berbeda halnya dengan Amerika Serikat dan Uni Eropa yang telah menerima dan mempraktikkan pembuktian tidak langsung ${ }^{5}$, UndangUndang Praktik Monopoli dan Persaingan Usaha Tidak Sehat di

4 Udin Silalahi, Prosiding seminar eksaminasi putusan perkara No. 08/ KPPUI/2014 (Dugaan pelanggaran terhadap Pasal 5 ayat (1) dan Pasal 11 UU No. 5/1999 dalam industri ban (Tangerang: Fakultas Hukum Universitas Pelita Harapan. (Ed.), 2015), 11.
Indonesia belum mengatur mengenai penggunaan bukti tidak langsung (indirect evidence) sebagai alat bukti untuk membuktikan terjadinya kartel. Dalam hal ini ketika KPPU memutus dugaan pelanggaran terhadap ketentuan-ketentuan dalam UndangUndang Nomor 5 Tahun 1999 harus berdasarkan pada alat bukti sebagaimana diatur dalam Pasal 42 yaitu: 1) keterangan saksi; 2) keterangan ahli; 3) surat dan/atau dokumen; 4) petunjuk; dan 5) keterangan pelaku usaha.

Proses Pembuktian dalam sebuah indikasi pelanggaran UU No. 5 tahun 1999 yang dilakukan oleh KPPU adalah kebenaran materiil. Kebenaran materiil adalah kebenaran yang bersumber pada kaidah-kaidah yang diatur dalam peraturan perundangundangan. Dalam Hukum Perdata yang dicari adalah kebenaran formil. Pencarian kebenaran materiil untuk membuktikan bahwa adanya akibat dari persaingan usaha tidak sehat tersebut, diperlukan keyakinan KPPU bahwa pelaku usaha melakukan atau

${ }^{5}$ Ahmad Junaidi, Pembuktian Cartel dalam UU No. 5/1999 (Majalah Kompetisi, 11.2008), 9 . 
tidak melakukan perbuatan yang menyebabkan terjadinya praktek monopoli atau persaingan usaha tidak sehat. Keyakinan itu didapat dengan cara memastikan kebenaran atas laporan dan inisiatif KPPU atas dugaan terjadinya praktek kartel dengan cara melakukan penelitian, pengawasan, penyelidikan, dan pemeriksaan. Undang-Undang Nomor 5 Tahun 1999 Tentang Larangan Praktek Monopoli dan Persaingan Usaha Tidak Sehat dalam pasal 42 disebutkan ada lima alat bukti yang dapat digunakan bagi Komisi Pengawas Persaingan Usaha yaitu; keterangan saksi, keterangan ahli, surat dan atau dokumen, petunjuk dan keterangan pelaku usaha. Dalam KUHAP dan HIR alat bukti langsung tersebut diajukan masing-masing dalam pasal 184 dan 164 .

Terdapat beberapa permasalahan yang timbul dengan penggunaan Indirect Evidence dalam indikasi kartel. Dalam pedoman pasal 11 Peraturan Komisi Pengawas Persaingan usaha disebutkan bahwa "KPPU harus berupaya memperoleh satu atau lebih alat bukti". ${ }^{6}$ Pernyataan

\footnotetext{
6 Peraturan Komisi Pengawas Persaingan Usaha No 4 Tahun 2010 Tentang
}

tersebut dapat diartikan bahwa satu alat bukti cukup untuk menindaklanjuti laporan ataupun dugaan adanya indikasi kartel. Hal ini bertentangan dengan Hukum acara pidana. Hukum pidana menyatakan "satu bukti bukan bukti" (unus testis nullus testis). Minimal alat bukti yang sah menurut KUHAP, yaitu dua alat bukti. Ketidaksesuaian hukum pembuktian antara ketentuan pembuktian yang ada dalam hukum acara pidana dan hukum persaingan usaha yang kemudian menjadikan latar belakang penulisan skripsi. Hukum acara pidana menggunakan Direct Evidence sebagai bukti utama dalam hukum acara pidana, sedangkan Indirect Evidence yang menjadi dasar utama pembuktian di dalam hukum persaingan usaha. Penulis merasa tertarik meneliti permasalahan ini dalam suatu penelitian dengan judul "Penggunaan Indirect Evidence (Alat Bukti Tidak Langsung) dalam Proses Pembuktian Dugaan Praktik Kartel di Indonesia Oleh KPPU”.

Ketidaksesuaian sistem pembuktian antara hukum acara pidana, hukum acara perdata dan

Pedoman Pasal 11 Tentang Kartel Berdasarkan UU No. 5 Tahun 1999 (Copyright@KPPU, 2011), 23. 


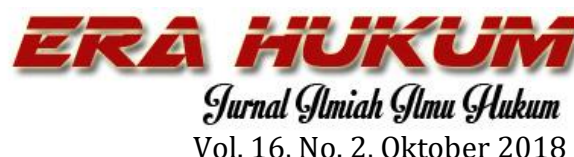

hukum acara persaingan usaha ini yang kemudian menjadikan penulis merasa tertarik untuk melakukan penelitian dan penulisan dalam jurnal yang berjudul "Penggunaan Indirect Evidence (Alat Bukti Tidak Langsung) dalam Proses Pembuktian Dugaan Praktik Kartel di Indonesia Oleh KPPU”.

\section{B. Perumusan Masalah}

Berdasarkan latar belakang di atas dapat dirumuskan beberapa rumusan masalah yang ingin diteliti sebagai berikut:

1. Bagaimanakah penggunaan Indirect Evidence dalam proses pembuktian menurut sistem hukum pembuktian di Indonesia?

2. Apakah penggunaan Indirect Evidence dapat digunakan oleh KPPU dalam membuktikan adanya dugaan kartel?

\section{Metode Penelitian}

\section{Tipe Penelitian}

Tipe penelitian yang digunakan adalah yuridis normatif yaitu teknik atau prosedur telaah dengan berpedoman pada beberapa asas
Ibnu Akhyat Penggunaan Indirect Evidence...

hukum, kaidah-kaidah hukum, maupun prinsip-prinsip hukum yang berkaitan dengan substansi peraturan perundang-undangan yang bersifat umum dan khusus dan dilakukan observasi lapangan yang dilakukan dalam rangkaian mengetahui penggunaan Indirect Evidence dalam proses pembuktian telah sesuai menurut sistem hukum pembuktian di Indonesia.

\section{Metode Pendekatan}

Pendekatan masalah yang dipergunakan penulis adalah dengan pendekatan perundang-undangan (statute approach) dan pendekatan konseptual (conceptual approach).

Pendekatan perundang-undangan (statute approach) dilakukan dengan menelaah semua undang-undang dan regulasi yang bersangkut paut dengan isu hukum yang sedang ditangani. Penulisan ini bertitik tolak dari peraturan perundang-undangan, dengan menekankan pada pencarian norma yang terkandung dalam ketentuan perundang-undangan maupun peraturan lain yang berkaitan dengan permasalahan penulisan ini dengan mempelajari dan menguraikan 


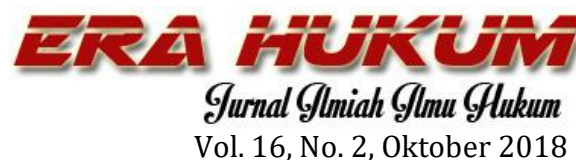

norma-norma dan Pasal-Pasal yang terkait pada rumusan masalah yang telah diterapkan.

Pendekatan konseptual (conceptual approach), adalah beranjak dari pandangan-pandangan dan doktrin-doktrin yang berkembang di dalam ilmu hukum. Mulai dari konsep terkecil pada norma hukum dan teori hukum yang selanjutnya dirumuskan dalam bentuk preposisi atau rangkaian konsep, sehingga konsep tersebut merupakan unsur terkecil dari teori hukum maupun norma hukum yang berkaitan dengan rumusan masalah yang telah ditetapkan.

\section{Hasil dan Pembahasan}

\section{Kartel}

\section{a. Penetapan Harga}

Dalam Undang-Undang Nomor 5 Tahun 1999, larangan mengenai perjanjian penetapan harga diatur dalam Pasal 5 ayat (1) yaitu pelaku usaha dilarang membuat perjanjian dengan pelaku usaha pesaingnya untuk menetapkan harga atas suatu barang dan/atau jasa yang harus dibayar oleh
Ibnu Akhyat Penggunaan Indirect Evidence...

konsumen atau pelanggan pada pasar bersangkutan yang sama. Berdasarkan Peraturan KPPU Nomor 4 Tahun 2011 tentang Pedoman Pasal 5 (Penetapan Harga) Undang- Undang Nomor 5 Tahun 1999, terdapat beberapa hal yang perlu diperhatikan sehubungan dengan ketentuan Pasal 5, yaitu sebagai berikut:

1) Perjanjian Penetapan Harga

Penetapan harga yang dilarang sesuai dengan Pasal 5 Undang-Undang Nomor 5 Tahun 1999 adalah penetapan harga yang berasal dari suatu perjanjian. Tanpa adanya perjanjian, maka kesamaan harga yang ditetapkan oleh suatu perusahaan dan perusahaan lain tidak dapat dikatakan melanggar Pasal 5.

2) Antar Pelaku Usaha dengan Pelaku Usaha Pesaingnya

Pelanggaran Pasal 5 UndangUndang Nomor 5 Tahun 1999 hanya terjadi jika terdapat perjanjian penetapan harga antara pelaku-pelaku usaha yang berada di dalam pasar bersangkutan yang sama.

3) Harga yang Dibayar oleh Konsumen atau Pelanggan

Dalam Pasal 5 ayat (1) dinyatakan 


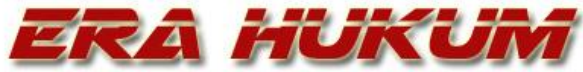 \\ Gurnal Glmiah Glmu Glukum \\ Vol. 16, No. 2, Oktober 2018}

bahwa pelaku usaha dilarang melakukan perjanjian penetapan harga atas suatu barang dan/atau jasa. Penetapan harga yang dimaksud di sini tidak hanya penetapan harga akhir, melainkan juga perjanjian atas struktur atau skema harga. Karena di dalam ayat tersebut, penetapan harga tidak berarti penetapan harga yang sama. Misalkan ketika perusahaanperusahaan yang berkolusi memiliki produksi dengan berbagai kelas yang berbeda, maka kesepakatan harga dapat berupa kesepakatan atas margin (selisih antara harga dengan biaya produksi). Akibatnya harga yang ada di pasar berbeda-beda untuk perusahaan dengan kelas produksi yang berbeda, namun margin yang diperoleh perusahaan-perusahaan di pasar akan sama.

Apabila dilihat dari rumusannya maka pasal yang mengatur mengenai penetapan harga ini dirumuskan secara per se illegal sehingga penegak hukum dapat langsung menerapkan pasal ini kepada pelaku usaha yang melakukan perjanjian penetapan harga tanpa harus mencari alas an-alasan mereka melakukan perbuatan tersebut atau

7 Andi Fahmi Lubis, Hukum Persaingan Usaha Antara Teks \& Konteks
Ibnu Akhyat

Penggunaan Indirect Evidence...

tidak diperlukan pembuktian perbuatan tersebut menimbulkan terjadinya praktik monopoli atau persaingan usaha tidak sehat ${ }^{7}$. Selain itu, akibat dari penetapan harga tersebut langsung dirasakan oleh konsumen, karena harga di tingkat konsumen bukan lagi harga berdasarkan permintaan (demand) dan penawaran (supply) tetapi karena ditetapkan oleh para pelaku usaha yang seharusnya bersaing.

\section{b. Pembagian Wilayah}

Dalam Undang-Undang Nomor 5 Tahun 1999, larangan mengenai perjanjian pembagian wilayah diatur dalam Pasal 9 yaitu pelaku usaha dilarang membuat perjanjian dengan pelaku usaha pesaingnya yang bertujuan untuk membagi wilayah pemasaran atau alokasi pasar terhadap barang dan/atau jasa sehingga dapat mengakibatkan terjadinya praktik monopoli dan/ atau persaingan usaha tidak sehat. Yang dimaksud dengan pembagian wilayah atau alokasi pasar di antaranya:

(Jakarta: Komisi Pengawas Persaingan Usaha, 2009) 91-92. 
a. Membagi wilayah untuk memperoleh atau memasok barang dan/atau jasa;

b. Menetapkan dari siapa saja dapat memperoleh atau memasok barang dan/atau jasa. ${ }^{8}$

Ketentuan yang mengatur mengenai perjanjian pembagian wilayah dalam Pasal 9 UndangUndang Nomor 5 Tahun 1999 dirumuskan secara rule of reason sehingga perlu dibuktikan apakah perbuatan tersebut mengakibatkan terjadinya praktik monopoli dan/atau persaingan usaha tidak sehat atau apakah pelaku usaha mempunyai alasan-alasan yang dapat diterima secara akal sehat. ${ }^{9}$

\section{c. Pengaturan Produksi dan/atau Pemasaran}

Dalam Undang-Undang Nomor 5 Tahun 1999, larangan mengenai perjanjian pengaturan produksi dan/atau pemasaran barang dan/atau jasa diatur dalam Pasal 11 yaitu pelaku usaha dilarang membuat perjanjian dengan pelaku pesaingnya yang

8 Susanti Adi Nugroho, Hukum Persaingan Usaha di Indonesia dalam Teori \& Praktik Serta Penerapan Hukumnya (Jakarta: Kencana Prenadamedia Group, 2012), 161.

${ }^{9}$ Andi Fahmi Lubis, et.al., Hukum Persaingan Usaha Antara Teks dan Konteks (Jakarta: Komisi Pengawas Persaingan Usaha, 2009), 101. 


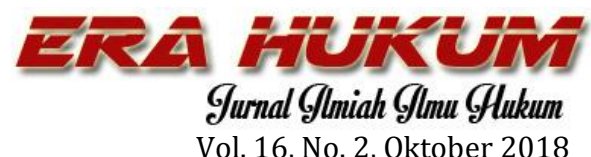

dengan pelaku usaha pesaingnya yang bermaksud untuk memengaruhi harga dengan mengatur produksi atau pemasaran barang atau jasa asalkan tidak mengakibatkan terjadinya praktik monopoli dan persaingan usaha tidak sehat. ${ }^{10}$

\section{Pembuktian Menurut Sistem Hukum Pembuktian di Indonesia}

\section{a. Sistem Pembuktian}

Dalam ilmu pengetahuan hukum acara pidana dikenal tiga teori tentang sistem pembuktian yang meliputi: 1) Sistem pembuktian menurut undangundang secara positif (positief wettelijke bewijs theorie); 2) sistem pembuktian menurut keyakinan hakim; dan 3) sistem pembuktian menurut undang-undang secara negatif (negatief wettlijk bewijs theorie $)^{11}$

Ada suatu perbedaan yang tajam antara pembuktian dalam hukum acara pidana dan pembuktian dalam hukum acara perdata. Sistem pembuktian

\footnotetext{
${ }^{10}$ Ibid., 108.

11 Salim\& Nurbani, E.S. Penerapan Teori Hukum Pada Penelitian Disertasi \& Tesis (Jakarta: PT. RajaGrafindo Persada, 2016), 228
}

Ibnu Akhyat Penggunaan Indirect Evidence...

dalam acara pidana dikenal dengan sistem negatif. Yang dimaksud dengan sistem negatif adalah suatu sistem pembuktian di depan pengadilan agar suatu pidana dapat dijatuhkan oleh hakim haruslah memenuhi dua syarat mutlak yaitu alat bukti yang cukup dan keyakinan hakim. ${ }^{12}$ Terdapat beberapa macam jenis hukum acara di pengadilan secara umum yang ada di Indonesia untuk membuktikan suatu perkara di persidangan. Hukum acara yang dimaksud disini adalah Hukum acara Pidana, hukum acara perdata, hukum acara persaingan usaha. Hukum acara pidana secara khusus diatur dalam Kitab Hukum Acara Pidana, hukum acara perdata secara khusus diatur dalam Kitab Hukum Acara Perdata atau HIR dan Hukum Acara Persaingan Usaha diatur dalam peraturan Komisi Pengawas Persaingan Usaha (Perkom) Nomor 1 tahun 2010 Tentang Tata Cara Penanganan Perkara.

Prinsip pembuktian tentang adanya pelanggaran dalam UndangUndang Nomor 5 Tahun 1999 sama dengan prinsip pembuktian dalam

12 Munir Fuady, Teori Hukum Pembuktian (Pidana \& Perdata), (Bandung: PT. Citra Aditya Bakti, 2006), 2. 
perkara pidana yang berlaku dalam

KUHAP yaitu dengan berpedoman pada Pasal 183 KUHAP yang mengatur bahwa untuk menentukan kesalahan seorang harus didasarkan pada sekurang-kurangnya dua alat bukti yang sah dan diperoleh keyakinan bahwa suatu tindak pidana benar-benar telah terjadi. ${ }^{13}$

Terdapat perbedaan-perbedaan antara penggunaan pembuktian menurut hukum acara persaingan usaha, hukum acara perdata, dan hukum acara pidana. Pembuktian adalah suatu tahapan di dalam hukum untuk meneliti kebenaran atas suatu perkara hukum. Fokus penulis dalam perbedaan ini terletak pada penggunaan alat bukti tidak langsung pada hukum persaingan usaha terhadap hukum acara perdata dan hukum acara pidana. Hukum acara pidana secara tegas mengatur dalam pasal 184 KUHAP "alat bukti yang sah, yaitu: keterangan saksi; keterangan ahli; surat; petunjuk; keterangan terdakwa". Hukum pembuktian di dalam sistem hukum acara pidana tidak dikenal adanya alat

13 Susanti Adi Nugroho, Hukum Persaingan Usaha di Indonesia dalam Teori \& Praktik Serta Penerapan Hukumnya bukti langsung dan tidak langsung.

Di sisi lain hukum acara perdata dalam pasal 164 HIR menyebutkan alat bukti yang sah, yaitu: bukti surat; bukti saksi; sangka; pengakuan; sumpah. Pengelompokkan bukti tidak langsung dan bukti langsung dijelaskan dalam buku M. Yahya Harahap sebagai berikut: "Disebut bukti langsung, karena diajukan secara fisik oleh pihak yang berkepentingan di depan persidangan”. “.....Pembuktian yang diajukan tidak bersifat fisik, tetapi yang diperoleh sebagai kesimpulan dari hal atau peristiwa yang terjadi di persidangan". ${ }^{14}$ Dilihat dari bentuk fisik tersebut maka yang menjadi alat bukti tidak langsung menurut hukum acara perdata yaitu persangkaan, pengakuan dan sumpah. Bentuk fisik ketiga alat bukti tidak langsung ini dapat dikatakan sebagai suatu kesimpulan dari hak atau peristiwa yang terjadi di persidangan. Secara umum istilah Indirect dan Direct Evidence tidak begitu akrab dalam lingkungan fakultas Hukum. Baik Kitab hukum acara pidana, Kitab

(Jakarta: Kencana Prenadamedia Group, 2012), 603.

14 M. Yahya Harahap, Hukum Acara Perdata (Jakarta: Sinar Grafika, 2008), 558. 
hukum acara perdata tidak mencantumkan kedua istilah tersebut.

\section{b. Alat Bukti}

Dalam proses pemeriksaan, KPPU memerlukan bukti-bukti bahwa pelaku usaha yang bersangkutan melanggar Undang-Undang Nomor 5 Tahun 1999 dan peraturan pelaksananya. Adapun alat-alat bukti yang digunakan oleh KPPU berbeda dengan alat-alat bukti yang digunakan hukum acara perdata tetapi mirip dengan alat-alat bukti yang tercantum dalam KUHAP. Dalam Pasal 42 Undang-Undang Nomor 5 Tahun 1999 jo. Pasal 72 Peraturan KPPU Nomor 1 Tahun 2010, alat-alat bukti pemeriksaan KPPU terdiri dari:
a) Keterangan saksi;
b) Keterangan ahli;
c) Surat dan/atau dokumen;
d) Petunjuk; dan
e) Keterangan pelaku usaha

Dalam Pasal 42 Undang-Undang Nomor 5 Tahun 1999, alat bukti pemeriksaan KPPU terdiri dari keterangan saksi, keterangan ahli,

15 Susanti Adi Nugroho, Hukum Persaingan Usaha di Indonesia dalam Teori \& Praktik Serta Penerapan Hukumnya 
termasuk dalam pengertian petunjuk dalam KUHAP. Menurut Hansen, penggunaan alat bukti petunjuk dalam perkara monopoli dan persaingan usaha tidak dapat disamaratakan, melainkan ditentukan kasus per kasus. Dalam hal ini petunjuk dapat dijadikan sebagai alat bukti asalkan petunjuk itu mempunyai kesesuaian dengan petunjuk lainnya atau sesuai dengan perbuatan atau perjanjian yang diduga melanggar Undang-Undang Nomor 5 Tahun 1999. ${ }^{16}$

Bukti tidak langsung (indirect evidence) adalah suatu bentuk bukti yang tidak secara langsung menyatakan adanya kesepakatan namun dapat digunakan sebagai pembuktian awal terhadap kondisi atau keadaan yang dapat dijadikan sebagai dugaan adanya perjanjian lisan atau praktik kartel. $^{17}$ Bukti-bukti dalam indirect evidence yang menunjukkan kesesuaian dengan alat bukti lain membentuk suatu petunjuk atas adanya suatu perjanjian tidak

16 Andi Fahmi Lubis, et.al., Hukum Persaingan Usaha Antara Teks dan Konteks (Jakarta: Komisi Pengawas Persaingan Usaha, 2009), 329.

17 Udin Silalahi, Prosiding seminar eksaminasi putusan perkara No. 08/ KPPU. I/2014 (Dugaan pelanggaran terhadap Pasal 5 ayat (1) dan Pasal 11 UU No. 5/1999 dalam tertulis. $^{18}$

Dengan demikian, syarat penggunaan indirect evidence adalah terdapat kesesuaian antara bukti-bukti yang disebut sehingga kesesuaian antara bukti-bukti tersebut membentuk hanya satu alat bukti yaitu menjadi bukti petunjuk. Dalam hal ini seluruh faktor yang ditemukan wajib diaplikasikan melalui metodologi yang teruji baik secara ilmiah dan konsisten sehingga kesimpulannya dapat dipertanggungjawabkan. ${ }^{19}$ Oleh karena itu KPPU dalam memutuskan terjadinya pelanggaran terhadap UU No. 5 Tahun 1999 dapat menggunakan bukti tidak langsung (indirect evidence) sebagai pembuktian awal terhadap dugaan adanya perjanjian kartel antar pelaku usaha namun dalam memutuskan terjadinya pelanggaran tersebut KPPU tetap harus memperhatikan dan menggunakan alat bukti sebagaimana diatur dalam Pasal 42 Undang-Undang Nomor 5 Tahun 1999.

industri ban, (Tangerang: Fakultas Hukum Universitas Pelita Harapan 2015), 6.

18 Ibid., 7.

19 Udin Silalahi, Prosiding seminar publik eksaminasi akademik putusan-putusan Komisi Pengawas Persaingan Usaha dikaitkan dengan draft Amandemen UU No. 5/1999 (Tangerang: Fakultas Hukum Universitas Pelita Harapan 2017), 98. 
Dalam pembuktian perkara kartel bukti tidak langsung (indirect evidence) tidak dapat dipergunakan sebagai satu-satunya alat bukti. ${ }^{20}$ Untuk menilai terjadinya pelanggaran terhadap Undang-Undang Nomor 5 Tahun 1999, KPPU harus menggunakan alat-alat bukti sebagaimana diatur dalam Pasal 42 yaitu terdiri dari keterangan saksi, keterangan ahli, surat dan/ atau dokumen, petunjuk, dan keterangan terlapor. Apabila bukti tidak langsung (indirect evidence) digunakan maka kedudukannya adalah sebagai bukti pendukung atau penguat dari bukti di atas. Dalam hal terdapat kesesuaian antara bukti-bukti yang disebut maka kesesuaian antara bukti-bukti tersebut membentuk hanya satu alat bukti yaitu menjadi bukti petunjuk. $^{21}$

Pembuktian dengan menggunakan bukti langsung sebagaimana diatur dalam Pasal 42 harus dilakukan terutama dalam membuktikan terjadinya pelanggaran Pasal 5 ayat (1) Undang-Undang Nomor 5 Tahun 1999. Hal ini

20 Udin Silalahi, Prosiding seminar eksaminasi putusan perkara No. 08/ KPPUI/2014 (Dugaan pelanggaran terhadap Pasal 5 ayat (1) dan Pasal 11 UU No. 5/1999 dalam industri ban, (Tangerang: Fakultas Hukum Universitas Pelita Harapan 2015),6. dikarenakan ketentuan dalam Pasal 5 ayat (1) menggunakan pendekatan per se illegal di mana pelaku usaha dapat langsung dinyatakan bersalah melanggar Undang-Undang Nomor 5 Tahun 1999 apabila ditemukan adanya perjanjian penetapan harga tanpa perlu dibuktikan apakah akibat dari perbuatan tersebut menyebabkan terjadinya praktik monopoli dan/atau persaingan usaha tidak sehat. Oleh karena itu bukti langsung diperlukan dalam pembuktian pelanggaran Pasal 5 ayat (1) Undang-Undang Nomor 5 Tahun 1999.

Perlu diperhatikan pula bahwa prinsip pembuktian tentang adanya pelanggaran dalam Undang-Undang Nomor 5 Tahun 1999 mensyaratkan sekurang-kurangnya dua alat bukti yang sah dan diperoleh keyakinan bahwa suatu tindak pelanggaran terhadap ketentuan Pasal 5 ayat (1) dan Pasal 11 benar-benar telah terjadi. Dengan adanya persyaratan paling sedikit dua alat bukti yang sah tersebut, maka KPPU tidak dapat memutuskan suatu perkara kartel

21 Udin Silalahi, Prosiding seminar publik eksaminasi akademik putusan-putusan Komisi Pengawas Persaingan Usaha dikaitkan dengan draft Amandemen UU No. 5/1999 (Tangerang: Fakultas Hukum Universitas Pelita Harapan 2017), 98. 


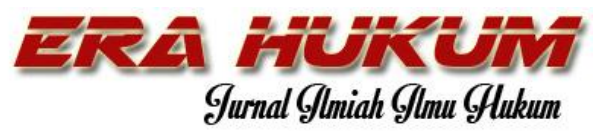

Vol. 16, No. 2, Oktober 2018

hanya pada bukti tidak langsung

(indirect evidence) saja. Penggunaan bukti tidak langsung (indirect evidence) dalam membuktikan perkara kartel harus dilakukan sesuai dengan prinsip dalam hukum pembuktian. Dalam hal ini KPPU harus menggunakan bukti tidak langung (indirect evidence) bersama-sama dengan alat bukti langsung yang lain dalam Pasal 42 untuk membuktikan terjadinya pelanggaran Pasal 5 ayat (1) dan Pasal 11 Undang-Undang Nomor 5 Tahun 1999. Hal ini dikarenakan bukti tidak langsung hanya sebagai alat bukti pendukung (plusfactors).

Dapat dipahami bahwa KPPU mengalami kesulitan untuk menemukan bukti langsung dalam membuktikan perkara kartel. Oleh karena itu seperti di Amerika Serikat, Uni Eropa, Jepang, dan lain-lain mengatur leniency program menjadi insentif untuk membongkar praktik kartel bagi peserta kartel. Konsep leniency program adalah keistimewaan bagi pelaku usaha yang terindikasi melakukan kartel. Syaratnya pelaku usaha tersebut bersedia membuka data dan informasi

${ }^{22}$ M.V. Tarnes, Bongkar kartel dengan leniency program. Diakses dari http:// www.hukumonline.com/berita/baca/
Ibnu Akhyat Penggunaan Indirect Evidence...

kepada KPPU mengenai kartel yang dilakukan. Konsep ini mirip "whistleblower" dalam hukum pidana. Pelaku kartel yang mengaku dan memberikan informasi kepada KPPU bisa mendapatkan insentif atau keringanan hukuman. ${ }^{22}$

\section{Penutup}

\section{A. Kesimpulan}

1. Bukti tidak langsung (indirect evidence) tidak sama dengan alat bukti dalam Pasal 42 UndangUndang Nomor 5 Tahun 1999.

2. Penggunaan bukti tidak langsung (indirect evidence) dalam membuktikan perkara kartel harus dilakukan sesuai dengan prinsip dalam hukum pembuktian.

3. Bila KPPU ingin menggunakan bukti tidak langung (indirect evidence), maka KPPU harus bersama-sama dengan menggunakan alat bukti langsung yang lain dalam Pasal 42 untuk membuktikan terjadinya pelanggaran Pasal 5 ayat (1) dan Pasal 11 Undang-Undang Nomor 5 Tahun 1999. 
4. Bukti tidak langsung hanya sebagai alat bukti pendukung (plusfactors).

\section{B. Saran}

Penulis memberikan beberapa saran untuk perbaikan pengaturan Hukum Persaingan Usaha di Indonesia:

a. Pertentangan penggunaan Indirect Evidence masih hadir di kalangan praktisi dan akademisi baik dosen maupun mahasiswa. Sebaiknya KPPU lebih menggiatkan sosialisasi tentang Indirect Evidence dan tata cara dan tahapan penggunaannya pada sistem pembuktian di KPPU dan kaitannya dengan sistem pembuktian di Indonesia.

b. Masih diperlukan sosialisasi terkait Tata Cara Penanganan Perkara yaitu Peraturan Komisi Pengawas Persaingan Usaha No. 1 tahun 2010 tentang tata Cara Penanganan Perkara jo. Perkom No. 1 tahun 2006.

c. Masih diperlukan pengaturan mengenai tata cara penanganan perkara yang lebih mendetail supaya jelas terlihat tahapan penggunaan indirect evidence oleh KPPU.

d. Pertimbangan hukum majelis hakim yang menerima bukti tidak langsung (indirect evidence) sebagai alat bukti dalam hukum persaingan usaha dapat menjadi terobosan hukum dalam penegakan hukum persaingan usaha di Indonesia, baik bagi KPPU, pengadilan negeri maupun di tingkat Mahkamah Agung. Apabila bukti tidak langsung (indirect evidence) ingin diterima sebagai alat bukti dalam membuktikan pelanggaran Undang-Undang Nomor 5 Tahun 1999, maka penggunaan bukti tidak langsung (indirect evidence) harus diatur dalam rancangan amandemen Undang-Undang Nomor 5 Tahun 1999 yang sedang dibahas di DPR saat ini yaitu bagaimana kedudukannya dalam pembuktian perkara kartel khususnya dalam penegakan Pasal 5 ayat (1) yang membutuhkan bukti langsung. 


\section{Daftar Pustaka}

Fuady, M., Teori Hukum Pembuktian

(Pidana \& Perdata), Bandung:

PT Citra Aditya Bakti, 2006.

Harahap. M, Yahya, Hukum Acara

Perdata, Jakarta: Sinar

Grafika, 2008.

Junaidi, A., Pembuktian Cartel dalam

UU No. 5/1999, Majalah

Kompetisi, 11, 2008.

Lubis, A.F., Hukum Persaingan

Usaha antara Teks \& Konteks,

Jakarta: Komisi Pengawas

Persaingan Usaha, 2009.

Nasution, F., \& Wiranti, R., Kartel dan

Problematikanya, Majalah

Kompetisi, 11, 2008.

Nugroho, S.A., Hukum Persaingan

Usaha di Indonesia dalam

Teori \& Praktik Serta

Penerapan Hukumnya.

Jakarta: Kencana

Prenadamedia Group, 2012.

Salim \& Nurbani, E.S., Penerapan

Teori Hukum pada Penelitian

Disertasi \& Tesis, Jakarta: PT

RajaGrafindo Persada, 2016.

Silalahi, U., Indirect evidence dalam hukum persaingan usaha, Jurnal Hukum Bisnis, 2013.

(Ed.).

Mengungkap kartel dengan bukti tidak langsung. Jakarta: ASEAN Competition Institute. (Ed.). (2015). Prosiding seminar eksaminasi putusan perkara No. 08/ KPPU-I/2014 (Dugaan pelanggaran terhadap Pasal 5 ayat (1) dan Pasal 11 UU No. 5/1999 dalam industri ban. Tangerang: Fakultas Hukum Universitas Pelita Harapan.

(Ed.). (2017). Prosiding seminar publik eksaminasi akademik putusan-putusan Komisi Pengawas Persaingan Usaha dikaitkan dengan draft Amandemen UU No. 5/1999. Tangerang: Fakultas Hukum Universitas Pelita Harapan.

Tarnes, M.V., Bongkar kartel dengan leniency program, Diakses dari http://

www.hukumonline.com/berita /baca/ lt4d81f77e90173/bongkarkartel-denganleniencyprogram, 2011. 